\title{
Journal of Information Literacy
}

ISSN 1750-5968

Volume 15 Issue 2

June 2021

\section{Article}

Inskip, C., \& Donaldson, S. 2021. Exploring effective information use in an insurance workplace. Journal of Information Literacy, 15(2), pp.45-77.

http://dx.doi.org/10.11645/15.2.2818

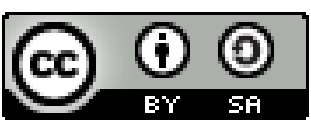

This work is licensed under a Creative Commons Attribution-ShareAlike 4.0 International License.

Copyright for the article content resides with the authors, and copyright for the publication layout resides with the Chartered Institute of Library and Information Professionals, Information Literacy Group. These Copyright holders have agreed that this article should be available on Open Access and licensed under a Creative Commons Attribution ShareAlike licence.

"By 'open access' to this literature, we mean its free availability on the public internet, permitting any users to read, download, copy, distribute, print, search, or link to the full texts of these articles, crawl them for indexing, pass them as data to software, or use them for any other lawful purpose, without financial, legal, or technical barriers other than those inseparable from gaining access to the internet itself. The only constraint on reproduction and distribution, and the only role for copyright in this domain, should be to give authors control over the integrity of their work and the right to be properly acknowledged and cited."

Chan, L. et al. 2002. Budapest Open Access Initiative. New York: Open Society Institute. Available at: http://www.soros.org/openaccess/read.shtml [Accessed: 18 November 2015] 


\title{
Exploring effective information use in an insurance workplace
}

\author{
Charles Inskip, Associate Professor, Department of Information \\ Studies, University College London. Email: c.inskip@ucl.ac.uk \\ ORCID: 0000-0002-4518-8794
}

\author{
Sophia Donaldson, Senior Careers Consultant, University College \\ London. Email: sophia.donaldson@ucl.ac.uk
}

\begin{abstract}
As employability has become a more visible graduate attribute, it is becoming recognised that a better understanding of information practices in work may enable a smoother transition from university to employment. This paper discusses the current state of workplace information literacy and presents the findings of research into staff experiences of information use in a City insurance firm. A framework previously developed out of phenomenographic research into nursing is employed to draw parallels and highlight differences between insurance workplace and university student terminology. Context-specific hierarchical statements using the language of the participants are developed from coded interview texts. These statements, which are drawn together in illustrative personae, provide a rich and detailed view of the participants' experience of effective information use. It is suggested that a better understanding of language use in communities of practice would facilitate transition both between and within the communities.
\end{abstract}

\section{Keywords}

information literacy; insurance; graduate employability; UK; workplace

\section{Introduction}

Information literacy (IL), a 'basic human right in a digital world' (Garner, 2005), is a challenging concept, with multiple definitions and conceptions. For some, the focus is on skills associated with finding, evaluating, using and creating information, while for others, it is more related to contextualised practices and experiences of information, or what could be called 'effective information use' (O'Farrill, 2010). Although the term was conceived in an employment context and originated within a discussion in the information industry (Zurkowski, 1974), the concept and practice of IL has predominantly been championed within libraries in Higher Education $(\mathrm{HE})$. Within $\mathrm{HE}$, it is considered a key element of learning, while in the wider workplace, it is more related to how employees contribute towards meeting the objectives of the organisation (Lundh et al., 2013). Outside the education system, and outside librarianship, the term itself is still rarely used in texts relating to skills, competences and attributes across sectors and levels, although small pockets of awareness of IL have been visible (Lloyd, 2006). In recent years there have been rapid developments in the literature demonstrating a sea change in awareness of the role of IL in the workplace (Goldstein, 2014, Inskip, 2014, Wiley, 2014, Williams et al., 2014, Molopyane and Fourie 2015, Forster 2017, Malafi, Liu et al. 2017, Binsfeld 2019, Forster 2019, Lockerbie and Williams 2019, Ahmad, Widén et al. 2020). These authors and others have recognised that workers engage constantly with information in many forms in their duties, and it is this engagement which enables them to make a contribution to the bottom line or help meet 
other objectives of their employment. If IL, which is well-developed in a university setting, was more visibly transferable to the workplace then this could improve graduate employability.

This research aims to explore the spoken experience of effective information use in a community of interest - an insurance workplace setting - and to compare that with the experience of nurses and of students through the application of a theoretical framework. The research questions were:

RQ1: how do people working in insurance articulate their experiences of effective information use?

$\mathrm{RQ2:}$ how do students planning to work in financial services articulate these experiences?

RQ3: are there unique terms used by each community which can help to identify any differences between these experiences?

RQ4: are there similarities between the experiences of effective information use between these professions and/or communities of interest?

Adopting the social constructionist belief that language creates reality (Burr, 2003; Andrews, 2012), this research is a qualitative study aiming to understand aspects of IL through the mapping of data onto a pre-existing framework developed through phenomenographic research (Forster, 2015). As such, it sets out to explore the spoken experience of effective information use in two communities of interest - in an insurance workplace setting and in a university - and to compare the experience of insurance workers with that of students and of nurses through the application of a theoretical framework, developed by Forster (2015). Deeper insight into language use has the potential to support human resources staff and careers consultants in identifying and evaluating the levels of IL of their clients and colleagues and contribute to jobhunting and self-development. Accordingly, the focus in the research is on the language used by the participants, as, in social constructionism, '... discourse and dialogue [are] the essential elements in people describing and producing their experiences' (Holland, 2006). Forster's framework (2015) identifies seven approaches to information use, and six information personae derived from his research into the experience of $\mathrm{IL}$ in the nursing profession. It is suggested that, although the terminology may vary between the differing contexts (insurance work, university students, nursing), the overall concepts and experiences may be comparable.

\section{Literature review}

While IL, 'the ability to think critically and make balanced judgements about any information we find and use' (Secker, 2018), has historically been university library-centred, it has expanded in scope to include communities of practice and wider society, where 'information landscapes' reflect an individual's context and experience (Lloyd, 2006). This paper draws from the wider view and considers IL to be a relational socio-cultural practice which contributes towards lifelong learning within communities of interest (Lloyd, 2012). The term 'practice' is used here, rather than 'behaviour' to distinguish between the cognitive emphasis in information behaviour research (examining external observable behaviours to draw inferences on internal unobservable forces such as needs and motives) and information practice research (an alternative to the dominant concept which is based on the belief that practices are social rather than individual) (Bates, 2010; Savolainen, 2007). Information practice, by its nature, reflects the context in which it sits. Meaning is negotiated, and routines and social rules within a community are influenced not only by the abilities, needs and motives of the individual, but also by the surrounding social and cultural factors (Talja et al., 2005; Tuominen et al., 2005). These 
'information landscapes' are textual, social and physical, and applicable to manual as well as white collar workers (Lloyd, 2010).

\subsection{Graduate employability}

Increasingly, IL is considered to be important not only for students' academic studies, but also for their employability and future careers (Pavlina et al., 2014). While job readiness is commonly recognised as a graduate attribute in vocational courses, it has not always been considered to be the primary purpose of all university education. In Europe, however, there has been a shift since the Bologna Process set out to align European standards in higher education (for example Johnson, 2013). In the UK, the Quality Assurance Agency (QAA) established a range of Subject Benchmark Standards (eg QAA, 2014) reinforcing employability as a graduate attribute and these standards have been used to inform employability profiles developed by the Higher Education Academy (Rees et al., 2006). Where employability features in courses' learning outcomes academics, librarians and careers consultants may have more opportunities to work together (Malafi, et al., 2017; Mawson \& Haworth, 2018). However, although IL has become more evident in education it is not so clear whether graduates are prepared for the information landscapes of the workplace.

Outside university, the business view of IL, for example, is pragmatic, centred on the pursuit of business objectives and profit. Leading business researcher Peter Drucker and others have recognised the relevance of competences specific to the use of information in terms of competitive advantage, making this a focus of the business school curriculum (Drucker, 1994; Hawes, 1994; Porter \& Millar, 1985). These curriculum developments were driven by the rapid increase in use of technology (Porter \& Millar, 1985), the business potential of knowledge management (Nonaka \& Takeuchi, 1995), and the impact of information overload (O'Sullivan, 2002). However, although IL was addressed in some business schools' curricula (eg Hawes, 1994), the term itself is rarely adopted by employers (Klusek \& Bornstein, 2006; Conley \& Gil, 2011; Axelsson et al., 2017). 'Information competency' is identified by Gilinsky and Robison (2008) as part of the role of business school curriculum delivery, while O'Farrill (2010) discusses 'effective information use', a more colloquial term which can be used to communicate the spirit of IL in the workplace setting to those unfamiliar with the term but experienced in the practice. Variations in terminology such as these may contribute to the reported difficulties in transferring information practices between discourse communities such as academic and work contexts (Quinn \& Leligdon, 2014). This communication challenge could be described as a 'semantic gap': a term used in computing to identify 'the difference in meaning between constructs formed within different representation systems' (Hein, 2010, p. 57) (such as computer code vs natural language), which may lead to communication problems.

\subsection{Workplace IL}

Important efforts have been made to understand information use and practice in the workplace, initially through information needs and behaviour studies which led to the development of various models for workplace information. These identified the 'invisible college' (or community of practice), gatekeepers and colleagues as sources and means of sharing information (Byström et al., 2016). These ideas were derived mostly from investigations into workplace information acquisition and use, and have led to the more recent focus on workplace IL. Some important differences between academia and the workplace have been identified: the transfer itself from study to work is difficult (Prince et al., 2015), the academic and workplace contexts are different (Lundh et al., 2013), in work people are often important information sources, the financial and production bottom lines are fundamental measures, there are strong cultural 
values and norms, projects are often ongoing, teamwork is the norm, and not all employees are willing or have an opportunity to engage in the formal learning process (Abram, 2013, p. 206). Social or situated learning and communities of practice contribute to the complexity of the workplace learning experience, far from academic frameworks.

The contextual nature of the workplace and the importance of people as information sources have been found to be central to workplace learning (or staff development), information use and behaviour, and IL (Lloyd \& Somerville, 2006, Crawford \& Irving, 2009, Fourie \& Julien, 2014). Klusek and Bornstein (2006) in their analysis of business and finance job profiles demonstrate the need for IL, which is 'valued' and 'integral' (2006, p. 3). Despite their emphasis on skills, they recognise the importance of cognition over technique in the pursuit of the 'outcome' identified by Chyung et al. (2006, p. 308). They mapped the American College and Research Libraries' (ACRL) IL Standards (ACRL, 2000) to job profiles in the US Department of Labor database ' $\mathrm{O}$ NNet'. They demonstrated the importance of problem-solving and analysis in the financial professions, and argued that educators should develop students' information skills within the curriculum to enhance their work preparedness for specific labour markets. Jinadu and Kaur (2014) and Wema (2013) find that in developing countries these differences are even more profound.

The difference between the workplace environment and the university setting also limits the relevance of the established IL models and frameworks so widely used in educational institutions. It is proposed by Li and Hung (2010) that if employers are aware of applicant and staff members' information literacies then this can inform the development of what is known as their Person/Job fit. Indeed they deem it 'critical', influencing job performance. Lloyd digs deeper into this relationship, stating that 'without information literacy, other work-related practices and performances couldn't be accomplished' (Lloyd, 2011), calling for a shift from a skills-based to a practice- or activity-based focus, which would more accurately represent the role of IL within the workplace context. She also critically discusses the often-default belief that IL may be easily transferable from one setting to the next. Because of its contextual nature and relationship with discourses of a setting, Lloyd asserts, IL cannot be seen as a set of skills, but as a collective practice related to a setting.

\subsection{Transitioning from university to work}

Students planning to enter the knowledge economy would benefit from understanding how information and knowledge are used in the workplace setting (Conley and Gil, 2011). However, unless the business community recognises the practice as IL then it is likely that it will not be widely adopted as such within the curriculum in Higher Education (Klusek and Bornstein, 2006). Efforts have been made to identify business information skills and competencies in order to encourage this adoption (Conley and Gil, 2011), suggesting that closer links between librarians, faculty and employers could lead to better mutual understanding. Costa (2009) asserts that a deeper understanding of the business information environment, which emphasises free online information, data and statistical indicators, and specialist subscription-based material, including grey literature, is necessary. She argues that as free resources are more widely used in the workplace than in university, this should inform the IL curriculum. Byström, et al (2017) identify the wide acknowledgement that work has a social nature, which is central to the operation of the information workplace (Paisley, 1968), contrary to the more solitary nature of study in Higher Education. Natt's more recent review identifies three intersecting 'information worlds' (2013): business literature, financial information, and competitor / industry information. He makes a strong case for recognising the different motivations in academia (thinking) and in the corporate world (doing). This contextual difference impacts on which competencies are relevant: 
environmental scanning, for example, in the workplace (Zhang et al., 2010). While Natt's discussion focuses on librarians, it could also help to explain why graduates do not always bring appropriate skills to the workplace. Phillips et al. (2019) discuss the difference in information needs and experience between undergraduate students and practicing engineers, recommending that a closer relationship between the curriculum and workplace information practice both in university and in the profession would ease transition into work. It has also been shown that IL is important at the top of the workplace hierarchy: Ahmad et al. (2020) suggest that IL not only benefits the institution through increasing productivity but at CEO level enhances organisational innovation - crucial in developing competitive advantage. They agree with Phillips et al. (2019) in recommending IL should be more evident in the student curriculum. The importance of the value of IL has also been identified as a concept which may encourage its adoption by employers (Sharun, 2019; Goldstein \& Whitworth, 2015) who are, on the whole, focused on the financial bottom line.

\subsection{Insurance, business management and financial work}

This research took place in a medium-sized global insurance firm based in the City of London. In the UK today the Chartered Insurance Institute (CII) provides an 'Insurance Competency Framework' (CII, 2017) which identifies numerous examples recognising the importance of information competency within the profession. Chyung et al. (2006) describe competency as being 'beyond a skill. It is not only about what one knows and can do but also whether one is able to accomplish a task and produce an outcome that is valued by both oneself and the organisation' (2006, p. 308), again reminding us of its contextual nature.

The Insurance Competency Framework is designed to inform employer-initiated workplace learning or staff development, identifying 'knowledge and skills that individuals must have to perform effectively at work' (2017, p. 4) and it appears in different levels of detail in each of their four stages of development (Induction, Core competence, Key competence, Professional), and as a Technical, Business, and Specialist competency. While the document identifies recognisable components of IL, emphasising 'how to gather, analyse, manage and store information effectively and securely' (2017, p. 21), the term 'information literacy' does not appear in the text. In the context of this Cll definition, 'effective information use' (O'Farrill, 2010; Marchand, 2000) could legitimately be adopted as an alternate term to IL. 'Effective information use' would include not only 'getting hold of information' (Bystrom et al., 2017 but also what they go on to describe as:

the other kinds of information-related activities such as choosing relevant information (sources), giving priority to some information over another, putting information in use, interpreting appropriate information needs, negotiating affordances of information systems available, etc. (Bystrom et al. 2017).

The term is also adopted by Hwang (2011) in a case study of a large insurance company. He applies an information orientation model (Marchand et al., 2000) in measuring the information behaviour performance of knowledge workers, finding that while employees were expert in information analysis, they were less skilled in managing information. Widén-Wulff (2003), in an in-depth study of insurance companies' information behaviour in Finland, highlighted the importance of valuing an active information culture in order to address the dynamic nature of the industry.

On the side of the educator, in the QAA Subject Benchmark Standards for Accounting, for Business Management, and for Economics (there are no such guidelines for Insurance), 
effective information use in one way or another is again recognised as being a key attribute (for example 'the ability to analyse and evaluate a range of business data, sources of information and appropriate methodologies, which includes the need for strong digital literacy, and to use that research for evidence-based decision-making'). The QAA standards recommend that 'graduates are able to collect relevant information across a range of areas pertaining to a current situation, analyse that information and synthesise it into an appropriate form in order to evaluate decision alternatives' and 'using information and knowledge effectively in order to abstract meaning from information and to share knowledge' at the end of a Masters' in Business Management course. These standards are used by universities to develop and evaluate undergraduate and postgraduate curricula and are widely applied across the UK Higher Education system. However, employers repeatedly say that graduates are still ill-prepared for the workplace in terms of their information abilities (Binsfeld, 2019; Goldstein, 2014; Head, 2017; Molopyane and Fourie, 2015; Wadson \& Phillips, 2018; Wiley, 2014).

This paper sets out to investigate how people experience IL in the insurance setting. It is hoped that the findings may contribute towards bridging the semantic gap for those on the move from university to insurance work.

\section{Methodology}

This section discusses the aims and objectives of the research and considers the methodological approach.

\subsection{Analytical framework}

A social constructionist approach is adopted, informed by the researchers' belief that '...we understand the world through mental categories but we acquire those categories through social relationships' (Gergen, 2015, p. 30), as the 'primary emphasis is not on mental, but on linguistic processes' (Talja et al., 2005, p. 89). The methodology used here adopts a framework developed in phenomenographic research (Forster, 2016). Phenomenography was developed by Swedish education researchers in the 1970s investigating learning (Marton, 1986). In this approach it is the experience of a phenomenon by the participants, rather than the phenomenon itself, which is of interest. Here it is the participants' experience of the phenomenon of IL in their professional context. Phenomenography is underpinned by the belief that although there are variations in the way a phenomenon may be experienced, these variations are limited in number, and they are consistently identified by the collective. It is also relational, meaning the phenomenon is inseparable from the individual - it is the relationship between them, often termed the 'experience', that is of interest. The phenomenon is seen as the combination of these experiences (Yates et al., 2012). An output of research of this type is a representation of the variations of experience in an 'outcome space', which represents the collective experience and is used to provide insights into the phenomenon. The approach has been adopted in IL research (Forster, 2016), particularly in work by UK/Australian researchers, and it is one of a suite of methods for IL (for example Limberg et al., 2012).

As previously stated, this research aims to explore the spoken experience of effective information use in a community of interest - an insurance workplace setting - and to compare that with the experience of nurses and of students through the application of a theoretical framework. The four research questions were:

RQ1: how do people working in insurance articulate their experiences of effective information use? 
$R Q 2$ : how do students planning to work in financial services articulate these experiences?

RQ3: are there unique terms used by each community which can help to identify any differences between these experiences?

RQ4: are there similarities between the experiences of effective information use between these professions and/or communities of interest?

The project has built on previous work, in particular that of Forster $(2015,2016,2019)$, by using his framework to guide the analysis of the data. Other frameworks with potential to be used for coding, such as SCONUL's Seven Pillars (SCONUL, 2011) and the ACRL Framework (ALA, 2015) and 'Seven pillars and five minds' (Lockerbie \& Williams, 2019) were discarded as methodological tools, Forster's being focused on the workplace was more relevant to the context. Although the terminology is likely to vary between differing contexts (insurance work, university students, nursing), and being mindful of the context determining the practice (Lloyd, 2011), the overall concepts and experiences may be similar. This would enable some comparison to be made between the two quite different professions (RQ4), which could be used to test Forster's framework (Forster, 2019). His investigation of nurses' conceptions of IL identifies seven 'Themes of expanding awareness' and six 'Categories of description', or 'Persona', which represent nurses' collective experience of IL (Forster, 2015). Each of his themes incorporates six increasing levels of awareness representing a wide range of experiences of the participants, from a basic to a sophisticated level. Forster then maps each level of awareness across the themes, giving rise to an outcome space of a set of six personae. This framework of themes and categories provides a view of the nurses' collective experience of IL in their workplace setting (Forster, 2013a). Forster's 'Themes of Expanding Awareness' are fully listed below (Table 1):

Table 1: Forster (2015, p. 197-199). Themes of expanding awareness

\begin{tabular}{|c|c|}
\hline \multicolumn{2}{|r|}{ IL experienced: } \\
\hline 1 & in processes of professional self-development \\
\hline 2 & $\begin{array}{l}\text { in development and maintenance of relationships (with patients, patients' families, } \\
\text { colleagues and other professionals) }\end{array}$ \\
\hline 3 & through its role in helping to achieve best practice \\
\hline 4 & within understandings and experiences of Evidence Based Practice \\
\hline 5 & within application of skills and processes of evidence and other information gathering \\
\hline 6 & $\begin{array}{l}\text { in the context of an understanding and knowledge of the principles and concepts } \\
\text { behind evidence and other information gathering }\end{array}$ \\
\hline 7 & through applicable conceptions of information \\
\hline
\end{tabular}

Each theme incorporates six increasing levels of awareness representing a wide range of experiences of the participants, from a basic to a sophisticated level. Forster maps each level of awareness across the themes, giving rise to an outcome space of a set of six categories of description, or personae (Table 2): 
Table 2: Forster (2015, p. 199). Categories of description

\begin{tabular}{|l|l|}
\hline Cat & \multicolumn{1}{c|}{ Description } \\
\hline A & The passive minimalist (creating knowledge to perform specific basic tasks) \\
\hline B & The knowledgeable goal achiever (creating knowledge for specific goals) \\
\hline C & $\begin{array}{l}\text { The focussed, competent and evolving professional (creating knowledge to } \\
\text { develop professional competence - to function effectively in particular day to day } \\
\text { roles) }\end{array}$ \\
\hline D & $\begin{array}{l}\text { The confident and trusted promoter of justifiable change (creating knowledge that } \\
\text { can be used as an agent of change through an understanding of situations and } \\
\text { contexts) }\end{array}$ \\
\hline E & $\begin{array}{l}\text { The teacher and promoter of an evidence-based culture (developing knowledge } \\
\text { infrastructures which allow specific roles to be performed of the kind which must be } \\
\text { based on a complete or almost complete understanding of a context or activity) }\end{array}$ \\
\hline $\mathrm{F}$ & $\begin{array}{l}\text { The leader, philosopher and strategist (developing knowledge infrastructures which } \\
\text { allow one to act as an established source or vector of 'wisdom' in various specific } \\
\text { contexts) }\end{array}$ \\
\hline
\end{tabular}

According to Forster's research, this framework of themes and categories provides a view of the participants' (nurses) collective experience of IL in their workplace setting and he uses this to draw inferences about the relative importance of various aspects of IL within their context which could be used to develop curricula or training programmes, for example around ethics (Forster, 2013a). While the themes and the categories were derived from research into nurses' experience of IL, the categories of description being described as 'archetypes' (Forster, 2015, p. 199) suggests they may lend themselves to being applicable in other work contexts.

\subsection{Context}

The Financial and Insurance sector has been in the top five most common graduate destinations for University College London (UCL) students for the last five years (according to Destinations of Leavers from Higher Education (DLHE) survey data (HESA, 2015)). It was therefore planned to gather data from a firm in this sector and also from students planning careers in the profession. The collaborative nature of the project was key here. The leaders of the project were a Library and Information Studies academic and a university Careers consultant. Their diverging perspectives and understandings allowed them to develop a participant recruitment strategy which would meet the project objectives. Initially the Careers office sought participants from the professional world. When this did not come to fruition the academic approached a CEO of a medium sized global insurance firm in the City of London, who agreed to host the research. Ethics approval was granted at university departmental Ethics Committee level, meeting the requirements of the institution. The researchers were careful to omit and obscure any information in the data which would be considered commercially sensitive, or could be used to identify the firm or the participants. The host provided access to 18 staff members from new entries to highly experienced executive directors. Each of these participants was given a summary of the research objectives in advance and completed an informed consent form during interview. Semi-structured interviews took place in the office building, lasted up to 45 minutes, were digitally recorded and transcribed by a professional transcription service. Two follow-up focus groups took place after work hours. A small group of 
6 students from a range of different courses but all planning to work in finance or insurance were recruited through the university Careers service mailing lists.

\subsection{Coding}

The interview transcriptions were checked for accuracy against the recordings by a volunteer MA Library and Information Studies student, and then read through 3 times by the researchers and imported into NVivo11 software. The questions for the insurance workers, which were informed by Forster's questions (Forster, 2013b), were firstly to speak about their current job, then to talk about the role of information in their work, and describe a person who does their job using information effectively. They were then asked to tell a story about a time when they used information effectively, and whether university prepared them for this. Finally they were also asked to describe their feelings and activities when doing a search and explain how they knew they had finished. The students were asked questions along similar lines, paraphrased to reflect their university context. The transcripts were initially coded according to the question topics, Early on in the coding, which helped the researchers to engage with the content of the interviews, similarities were noticed between these texts and those from Forster's work. It was subsequently decided to re-code the texts using Forster's 'Themes of expanding awareness' (TEA) (Forster, 2015, p. 197). Although this was time-consuming, the affordances of the software meant it was an efficient coding tool, allowing easy comparison between codes and between texts.

Once the texts had been coded using the Forster themes (Table 1) each category was examined and read through by both researchers for coding consistency and discussed and paraphrased where anomalies were found. This discussion process again allowed them more detailed insights into the nature of the texts and the variations of experience and allowed an iterative and reflective development of the coding. Importantly, it helped to identify and reconcile or otherwise address inconsistencies between the coded interview texts and the Forster framework where these arose. Again, here, the different viewpoints of the researchers contributed to these discussions, providing insights which probably would not have arisen if they had both come from the same field. Insights were also gathered from a support team consisting of a specialist subject librarian and an e-learning consultant who gave feedback on progress during the project.

\subsection{Analysis}

When the coding was complete, content analysis based on term frequency was applied because identifying frequent terms within each code would help identify language specific to each description (RQ1, RQ2). Unique meaningful terms in each coded text were then identified by comparing them against the codes of the full corpus data (RQ3). This would then enable comparisons between participant groups (employees and students) rather than individuals, and enable insights into differences between how they collectively expressed, and indeed constructed, their experiences of IL (RQ4). It was anticipated that this would then help to identify a semantic gap between the education and workplace settings which could help to explain the perceived disconnect and transition problems discussed earlier.

This approach, derived from corpus linguistics (Teubert \& Čermáková; 2007, Schmitt, 2010), has informed much search engines research, and term frequency is fundamental to the working of search engine technology, as frequency of terms in documents is matched to search enquiries to identify relevant documents (Hiemstra, 2000). More frequently occurring terms, therefore, can be used to partially identify meaning in documents (here, coded texts). Ranking 
these terms and choosing a cutoff $h$-point (where the ranking equals the frequency) is used in bibliometrics as a measure of researcher impact and, similarly here, was used as a way of identifying an appropriate cut-off point in choosing relevant terms from a ranked list (Teubert \& Čermáková, 2007; Popescu, 2007). The adoption of h-point rather than an arbitrary 'top 10' or 'top 25 ' frequently used terms means we were able to make comparisons between coded corpuses, because the value of the h-point is that it identifies a 'top $x$ ' list which is based on the actual frequency of the terms and their proportion in the corpus. This means that if in a corpus of, say, 10,000 words, the h-point is 10 (ie the $10^{\text {th }}$ word appears 10 times and the $11^{\text {th }}$ word appears 5 times) and in a similarly sized corpus from different data maybe the $11^{\text {th }}$ word appears 11 times this more refined value tells us something about the depth of the data. Inspired by the participants' extensive use of Microsoft Excel in their work, the researchers adopted the use of Excel spreadsheet macros (combining COUNTIF and VLOOKUP functions) to identify high frequency terms which were unique to each code. This automated task was much more efficient than initial pilot approaches, which had used colour marker pens on paper, and gave the researchers additional insights into the working practices of the participants.

The unique terms in each coded text had been identified by comparing them against the codes of the full corpus data. The texts had also been coded by dimensions of variation at a more granular hierarchic level (from basic to complex experience on a scale of $A-F$ ) as can be seen below (Table 3):

Table 3: Themes of expanding awareness codes and dimensions of variation

\begin{tabular}{|c|c|c|c|c|c|c|}
\hline $\begin{array}{c}\text { Self- } \\
\text { development } \\
\text { (SDV) }\end{array}$ & $\begin{array}{l}\text { Relationships } \\
\text { (REL) }\end{array}$ & $\begin{array}{c}\begin{array}{c}\text { Best } \\
\text { practice }\end{array} \\
\text { (BES) }\end{array}$ & $\begin{array}{c}\text { Evidence } \\
\text { Based } \\
\text { Practice } \\
\text { (EBP) }\end{array}$ & $\begin{array}{l}\text { Application } \\
\text { of skills } \\
\text { (SKL) }\end{array}$ & $\begin{array}{l}\text { Principles } \\
\text { and } \\
\text { concepts } \\
\text { (PRI) }\end{array}$ & (CON) \\
\hline SDV-A & REL-A & BES-A & EBP-A & SKL-A & PRI-A & CON-A \\
\hline SDV-B & REL-B & BES-B & EBP-B & SKL-B & PRI-B & CON-B \\
\hline SDV-C & REL-C & BES-C & EBP-C & SKL-C & PRI-C & CON-C \\
\hline SDV-D & REL-D & BES-D & EBP-D & SKL-D & PRI-D & CON-D \\
\hline SDV-E & REL-E & BES-E & EBP-E & SKL-E & PRI-E & CON-E \\
\hline SDV-F & REL-F & BES-F & EBP-F & SKL-F & PRI-F & CON-F \\
\hline
\end{tabular}

Terms were selected within each coding that occurred more than once but did not appear under other codes. For example, the result for multiple occurring terms uniquely in 'Self-developmentA' (SDV-A) was (Table 4) and for 'Self-development-B' (SDV-B) (Table 5):

Table 4: 'Self-development-A' (insurance) unique terms appearing more than once

excel, graphs, powerpoint, word, publisher, projects, studies, fields, library, luxury, pressure, reference, studying, analysing, graduated, researching 
textbook, emails, essay, term, academia, believer, contract, documents, firm, performance, plan, principles, searches, revision, marketing, mountain, order, specialty, managing, practicing, laundering, revising

Unique non-technical terms which were not stop-words (such as 'and', 'is', 'the' etc) were also retained. Each term was then examined in context for its collocations to verify its word class and meaning within the text. Based on the reading of each coded text these terms were then used by the researchers to construct phrases which conveyed the meaning of the discourse under that code, using the terminology of the participants.

In Forster's work, each theme contains hierarchical statements (dimensions of variation). In our findings Forster's themes and statements have been paraphrased, using highly ranked terminology in an attempt to represent the collective view of the participants in the project. It was found that coding texts using Forster's themes was relatively intuitive, and the themes mapped closely to the texts from the workplace. Within each theme, a granular hierarchy of dimensions of variation was also identifiable, although these dimensions were not easily mapped direct to Forster's themes. While Forster attempted to make these dimensions multicontextual and generalisable outside nursing, there were still instances of context-specific language (nursing, clinical, patient, etc) within the dimensions. These were removed or paraphrased to reflect the insurance context, and then reduced further to their basic meaning in order to analyse the texts more effectively. Once the texts had been broken into basic granular dimensions these were re-written adopting the unique terms discussed in the previous section (example in Table 6).

Table 6: Example of insurance unique terms applied to Forster Themes of Expanding Awareness

\begin{tabular}{|l|l|}
\hline $\begin{array}{l}\text { Nurses }-1^{\text {st }} \text { theme of expanding } \\
\text { awareness (Forster) }\end{array}$ & $\begin{array}{l}\text { Insurance }-\mathbf{1}^{\text {st }} \text { theme of expanding } \\
\text { awareness }\end{array}$ \\
\hline $\begin{array}{l}\text { IL experienced in processes of } \\
\text { professional self-development }\end{array}$ & $\begin{array}{l}\text { How do I become an effective } \\
\text { insurance information user? }\end{array}$ \\
\hline $\begin{array}{l}\text { A. Seeking out knowledge of clinical } \\
\text { contexts and conditions. } \\
\text { Investigate newly encountered } \\
\text { clinical conditions/situations. }\end{array}$ & $\begin{array}{l}\text { A. I have been studying and } \\
\text { researching the insurance } \\
\text { information field and language. I } \\
\text { develop key technical skills I need } \\
\text { (eg MS Office). }\end{array}$ \\
\hline B. Being a knowledgeable nurse. \\
$\begin{array}{l}\text { Establishing knowledge of, and } \\
\text { understanding of, current practice } \\
\text { and associate issues. }\end{array}$ & $\begin{array}{l}\text { B. I have developed my } \\
\text { understanding of insurance } \\
\text { principles from learning on-the- } \\
\text { job, a professional qualification, } \\
\text { and ad hoc support. }\end{array}$ \\
\hline $\begin{array}{l}\text { C. Achieving professional } \\
\text { competence. Showing } \\
\text { competence in day to day work. }\end{array}$ & $\begin{array}{l}\text { C. I have gone beyond the training, } \\
\text { and have practised complex } \\
\text { processes. I have shared my } \\
\text { experiences with others. }\end{array}$ \\
\hline D. Achieving professional \\
$\begin{array}{l}\text { confidence. Feeling confident in } \\
\text { one's role. Progressing }\end{array}$ & $\begin{array}{l}\text { D. My level of competence has been } \\
\text { recognised formally through } \\
\text { appraisals and informally through } \\
\text { day-to-day transactions. }\end{array}$ \\
\hline
\end{tabular}




\begin{tabular}{|l|l|}
\hline \multicolumn{1}{|c|}{$\begin{array}{l}\text { professionally. Becoming a } \\
\text { Lifelong learner. }\end{array}$} & \\
\hline E. $\begin{array}{l}\text { Achieving functional autonomy. } \\
\text { Becoming an adaptable, flexible } \\
\text { and responsive professional. } \\
\begin{array}{l}\text { Becoming able to function non- } \\
\text { dependently within the team. }\end{array}\end{array}$ & $\begin{array}{l}\text { E. I have a deeper understanding of } \\
\text { insurance information through } \\
\text { higher level skills and experience. }\end{array}$ \\
\hline F. $\begin{array}{l}\text { Having the ability to think } \\
\text { strategically and philosophically. } \\
\text { Becoming innovative in practice. } \\
\text { Developing a wider professional } \\
\text { horizon. }\end{array}$ & $\begin{array}{l}\text { F. I am equipped to critically reflect } \\
\text { on insurance information that is } \\
\text { passed to me. I use this to form } \\
\text { arguments and develop wider } \\
\text { business strategy. }\end{array}$ \\
\hline
\end{tabular}

While the student texts are discussed in the next section, it should be noted that a limitation of the study was the small number of student participants, caused by the timing of the research, which clashed with exams and summer break. This led to a smaller set of data from this group of participants, limiting the range of terminology used in the responses. They are included for completeness, but it is recognised that they are more indicative than conclusive.

\section{Findings}

This section summarises the findings under each theme and highlights links with research objectives.

\subsection{Insurance workers}

This section sets out to address research question 1: how do people working in insurance articulate their experiences of effective information use?

\section{In processes of professional self-development}

In the pursuit of becoming an 'effective insurance information user' ('in processes of professional self-development' (Forster, 2015, p. 197)) the insurance workers learn about the field, learn principles and pursue qualifications, practise processes at work and share these with others, are recognised for their competence, developing deeper understanding through experience and, finally, critically reflecting and informing business strategy. This supports Forster's progression relating to self- and professional development, seeking out information through becoming knowledgeable, competent, confident, autonomous and, ultimately, strategic. The experience of the workplace participants was very wide, since they were drawn from entrylevel to executive director.

\section{In development and maintenance of relationships}

The second theme, to utilise the links between people and information ('in development and maintenance of relationships' (Forster, 2015, p. 197)), again suggested a relationship between the experience of the insurers and the nurses. In this case the workplace participants identified friendly experts, took part in internal knowledge sharing (a very important part of the culture of this organisation), interacted with their colleagues to ensure the circulation of information, provided timely and focused information, recognising the needs of their colleagues and clients, shared their knowledge with their colleagues and encouraged and facilitated the sharing of 
information. This follows Forster's progression from passive to active interaction, on to functional relationships and autonomy, leading to a teaching and finally a leadership role.

\section{In helping to achieve best practice}

In terms of 'best practice' ('through its role in helping to achieve best practice' (Forster, 2015, p. 198)), the insurers followed Forster's progression from having sufficient background information to helping a multidisciplinary team with the information, in order to practice, to improve, to develop strategies and an information-rich culture and an ethical focus. Their professional context had more of a differing effect here, leading to their stated experiences of a willingness to learn to communicate it in a straightforward manner recognising a range of views, engaging in the peer review process, where work is checked by peers and managers throughout the process in order to meet mandates and minimise business risk, the role of accurate information in profitable operations, in business decisions and in regulatory needs. This theme, in terms of accurate information in the pursuit of meeting company and business objectives, was an important one within the interviews and generated some in-depth commentary across the sample. The peer review process, particularly, was brought up by the participants as a defining characteristic of their work, factual and numeric accuracy being very highly prized in a business which is founded on the minimisation and the monetisation of risk and uncertainty.

\section{Within understandings and experiences of Evidence Based Practice}

Insurers' experiences of evidence based practice ('within understandings and experiences of Evidence Based Practice' (Forster, 2015, p. 198)) were drawn by inference, as this was not mentioned by name. Indeed the participants barely addressed Forster's first level, relating to the following of guidelines, protocols and policy. However they did discuss a focus on relevant evidence, seeking out evidence, and experiencing it as a concept, a tool and a practice ideal. They spoke of using relevant evidence, using it to draw commercial conclusions, integrating evidence and their own ideas, appreciating it as a contributor to policy and protocols and, finally, understanding the importance of comprehensive, accurate and relevant evidence and an ability to evaluate this to minimise financial risk.

Within application of skills and processes of evidence and other information gathering The fifth theme was applying skills and processes of data and information gathering ('within application of skills and processes of evidence and other information gathering' (Forster, 2015, p. 198)). A decision was made here to remove Forster's 'evidence' as this seemed to be informed predominantly by the nursing evidence-based practice context. His progression, from using technology to knowing how to use resources and becoming skilled in their use, follows a coherent, purposeful and ultimately a strategic approach to data and information gathering and was very evident in the coded texts. The insurers confidently use software to aid efficient management and interpretation of numerical data, use a range of information sources, enjoy the research process and have an eye for detail, understand the strategic and decision-making purpose and the contribution it will make to the business, are purposeful in scanning and critical in picking relevant data and information from authoritative sources and are recognised for these attributes and abilities through the company appraisal system and informally on a day-to-day basis.

\section{In the context of an understanding and knowledge of the principles and concepts behind evidence and other information gathering}

The sixth theme involves an understanding and knowledge of the principles and concepts behind data and information gathering ('in the context of an understanding and knowledge of the principles and concepts behind evidence and other information gathering' (Forster, 2015, p. 
198)). Forster's progression identifies dimensions from knowledge of information types, information within the research context, the structure of databases, use of queries, construction of complex queries and, ultimately, arrives at an understanding of the purpose of information gathering. The insurers, here, were less detailed in their discussions, suggesting this is an area which is less important to them. So although they were clearly aware of technical knowledge of different sources and types of information and were aware of professional sector-specific sources and internal databases, knew something of the complexities, terms, and structures of insurance information and research and certainly were skilled in technical functions within data analysis (particularly pivot tables, knowledge of which is a badge of honour amongst these participants) and particularly large (and 'big') datasets, they had much less to say on keyword searching, search strategy and the purpose of searches.

\section{Through applicable conceptions of information}

The final theme was of appreciating different ideas and levels of information ('through applicable conceptions of information' (Forster, 2015, p. 199)). Forster discussed how these progress from basic facts through useful data to guidelines and protocols, to a wide and deep understanding, a basis for practice and, finally, a basis for strategy. Similarly, the insurers addressed basic financial and insurance data and terminology, qualitative and quantitative, economic, statistical data, metadata, trends and data generated from clients and internal sources, definitions of terminology, how data and awareness of its context contributes to deeper investigation, its role in problem solving and as a predictor. The participants seemed to emphasis this over the previous theme, suggesting that the value and importance to them of data which they analyse and interpret internally is greater than that of external information which they have searched for as part of their workflow. This is an important issue when considering the information use of these participants and how it may relate to incomers.

\subsection{Students}

This section sets out to address research question 2: how do students planning to work in financial services articulate these experiences?

\section{In processes of professional self-development}

The range of student experience is smaller - they are all of a similar age and experience level. They identified the use of resources provided by tutors and self-development supported by internal systems (library and VLE) but did not address the higher level categories of confidence, autonomy and a strategic approach.

\section{In development and maintenance of relationships}

Again the student texts did not map to all of these dimensions. The bulk of text was at the lowest level of the dimensions of variation when speaking about links between people and information ('I am good at identifying helpful experts who are able and willing to give me relevant information, support and advice. I seek guidance from people who know more than I do, like my lecturers, coursemates, friends, and library staff'). Although they were good at identifying friendly experts (lecturers, course-mates, friends and library staff) and also discussed and shared their ideas, formed peer networks and used their own ideas and opinions to inform their work, there were no comments relating to teaching and leadership.

\section{In helping to achieve best practice}

The students did not sufficiently address this theme in their responses to allow any meaningful conclusions. 


\section{Within understandings and experiences of Evidence Based Practice}

The students did not sufficiently address this theme in their responses to allow any meaningful conclusions.

\section{Within application of skills and processes of evidence and other information gathering} The students were quite detailed in their discussions of process. Although they did not speak of technology they did know where the library was and how to use it, picking up what they needed as they went, used a range of sources, narrowing down on specific details after a broad search, had a clear plan and knew when their search was complete, followed a very clear search strategy which categorised, prioritised and critiqued information and worked towards a goal, using information to inform and backup arguments, analysis and ideas. It seemed from these texts that the students were very well aware of the various skills and competences informing an effective search strategy and were at times using quite technical library terminology to discuss these. When addressing their own information and data gathering, the emphasis was at a higher level. It was clear that there is variation in experience which can be seen within and between the themes.

\section{In the context of an understanding and knowledge of the principles and concepts behind evidence and other information gathering}

Similarly to the insurance workers, the students' responses were somewhat patchy here. Although they identified specialist credible sources such as The Financial Times, The Economist and JSTOR they did not mention the specific research context. They did identify the difference between sources and, therefore, their role in the search and structure of a search and its purpose. Keywords (or similar) were not mentioned.

\section{Through applicable conceptions of information}

The students did not speak of basic data but were aware of the range of relative usefulness and relevance of data, using a wide range of sources, appreciating the importance of context, the value of data in 'making a difference' and the potential impact of critical thinking on making change happen.

\subsection{Personae}

The final step in Forster's work was to allocate Personae (Table 2). This was done by taking each variation of a similar level across the themes and drawing them together to identify an archetype: 'Passive minimalist; Knowledgeable goal achiever; Focussed, competent and evolving professional; Confident and trusted promoter of justifiable change; Teacher and promoter of an evidence-based culture; Leader, philosopher and strategist' (Forster, 2015, p. 199). The workplace and the student texts were similarly drawn together under these personae. It is important to recognise that the personae are intended as archetypes, and do not necessarily apply to individuals. Rather, they are intended to apply to the community as a whole, individuals demonstrating characteristics of different personae and switching discourse depending on the topic. Table 7 (below) provides examples of the two 'extremes' of persona, 'Passive minimalist' and 'Leader, philosopher and strategist' when applied to the insurance data and the student data. The full table of Personae (Appendix) demonstrates the similarities and differences between how the insurance workers and the students articulate their experiences of effective information use (RQ1, RQ2): while the Passive minimalist (nurse) 'seek[s] out knowledge of clinical conditions'; interacts passively with others, and knows about basic facts, the insurance worker studies and researches the insurance information field, identifies friendly experts, has baseline skills and is aware of basic financial and insurance data and terminology, the student seeks advice from experts and makes the most of the resources available to them. 
It should be noted that the students did not address all of the dimensions of variation, suggesting they were not thinking at higher levels, but equally, this could be due to the small sample, and would need further investigation. The full personae can be seen in the Appendix.

Table 7: Persona examples

\begin{tabular}{|c|c|c|}
\hline & \multicolumn{2}{|c|}{ Passive minimalist } \\
\hline Code & Insurance worker & Student \\
\hline SDV-A & $\begin{array}{l}\text { I have been studying and researching } \\
\text { the insurance information field and } \\
\text { language. I develop key technical skills } \\
\text { I need (eg MS Office). }\end{array}$ & $\begin{array}{l}\text { I make the most of the resources } \\
\text { provided by my course tutors e.g. } \\
\text { reading lists ensuring I'm familiar } \\
\text { with the curriculum. }\end{array}$ \\
\hline REL-A & $\begin{array}{l}\text { I am good at identifying friendly } \\
\text { experts who are able and willing to } \\
\text { give me relevant information and } \\
\text { advice. }\end{array}$ & $\begin{array}{l}\text { I am good at identifying helpful } \\
\text { experts who are able and willing to } \\
\text { give me relevant information, } \\
\text { support and advice. I seek } \\
\text { guidance from people who know } \\
\text { more than I do, like my lecturers, } \\
\text { coursemates, friends, and library } \\
\text { staff. I ask questions and request } \\
\text { feedback on my work from } \\
\text { lecturers, in order to perform } \\
\text { better. }\end{array}$ \\
\hline BES-A & $\begin{array}{l}\text { I have good baseline skills which } \\
\text { follow policy and protocols. I am willing } \\
\text { to build on these skills and have an } \\
\text { inquisitive and positive attitude to } \\
\text { learning. }\end{array}$ & \\
\hline EBP-A & $\begin{array}{l}\text { I seek out ways to understand the } \\
\text { process of insurance. I follow } \\
\text { guidelines, protocols and policy } \\
\text { documents. }\end{array}$ & \\
\hline SKL-A & $\begin{array}{l}\text { I confidently use software to help } \\
\text { manage and interpret numerical data } \\
\text { efficiently. }\end{array}$ & \\
\hline PRI-A & $\begin{array}{l}\text { I have background technical } \\
\text { knowledge of information sources and } \\
\text { types needed to research and use } \\
\text { data and information - such as } \\
\text { professional subscription sources for } \\
\text { the sector and internal databases. }\end{array}$ & $\begin{array}{l}\text { I am aware of information sources } \\
\text { and types needed to research and } \\
\text { use data and information. I know } \\
\text { which ones are considered } \\
\text { credible - such as the FT, The } \\
\text { Economist, JSTOR and special } \\
\text { library resources, as well as } \\
\text { articles recommended by lecturers. }\end{array}$ \\
\hline CON-A & $\begin{array}{l}\text { I usually think about basic financial } \\
\text { and insurance data and terminology. }\end{array}$ & \\
\hline
\end{tabular}




\begin{tabular}{|c|c|c|}
\hline & \multicolumn{2}{|c|}{ Leader, Philosopher and Strategist } \\
\hline SDV-F & $\begin{array}{l}\text { I am equipped to critically reflect on } \\
\text { insurance information that is passed to } \\
\text { me. I use this to form arguments and } \\
\text { develop wider business strategy. }\end{array}$ & \\
\hline REL-F & $\begin{array}{l}\text { I ensure processes are in place to } \\
\text { allow the sharing of information and } \\
\text { ideas with me and others. }\end{array}$ & \\
\hline BES-F & $\begin{array}{l}\text { I understand how best practice } \\
\text { impacts the business. I recognise the } \\
\text { vital role accurate information and data } \\
\text { play in profitable operations, company } \\
\text { performance and competitive } \\
\text { advantage. }\end{array}$ & \\
\hline EBP-F & $\begin{array}{l}\text { I creatively explore ideas. I draw from } \\
\text { experience and reliable information to } \\
\text { present a story which contributes to } \\
\text { the organisation's reputation. }\end{array}$ & \\
\hline SKL-F & $\begin{array}{l}\text { I understand the strategic and } \\
\text { decision-making purpose of the data } \\
\text { and information being gathered and } \\
\text { the contribution it will make to the } \\
\text { business. }\end{array}$ & $\begin{array}{l}\text { I have a clear understanding of my } \\
\text { overall goal. My search strategy, } \\
\text { and everything I do during my } \\
\text { search, works towards that goal. } \\
\text { The information I gather and use } \\
\text { serves a purpose. I use it to inform } \\
\text { and back up my own arguments, } \\
\text { analysis, and ideas. }\end{array}$ \\
\hline PRI-F & $\begin{array}{l}\text { I appreciate the ultimate purpose for } \\
\text { the business in information gathering. I } \\
\text { fully understand the need before I set } \\
\text { out to do the task. }\end{array}$ & $\begin{array}{l}\text { I understand that information } \\
\text { gathering has an objective, and I'm } \\
\text { aware of techniques that help pull } \\
\text { arguments together with analysis } \\
\text { of data to answer the question at } \\
\text { hand e.g. PEST analysis. }\end{array}$ \\
\hline $\mathrm{CON}-\mathrm{F}$ & $\begin{array}{l}\text { I see data and information as a basis } \\
\text { for predicting future events, reducing } \\
\text { uncertainty, and informing strategy } \\
\text { development. }\end{array}$ & $\begin{array}{l}\text { I see data and information as } \\
\text { things that need to be processed } \\
\text { using critical thinking, to provide } \\
\text { the basis for actual change, } \\
\text { strategy or theory that in future will } \\
\text { be beneficial in the real world. }\end{array}$ \\
\hline
\end{tabular}

\section{Discussion}

The theming and subsequent revisions of the statements presents a picture of the spoken experience of effective information use in these communities of interest. They provide insights into the collective experience of IL within this insurance workplace, and are constructed using 
the participants' own language in an attempt to more closely represent the experiences within this community of practice. Indeed, as Lave and Wenger (1991) identify, adopting the language of the community of practice enables legitimate peripheral participation in the community and thus, learning. This is reinforced by the h-point vocabulary of the unique workplace texts, which includes numerous terms specific to this community (Table 4, 5).

Within the workplace participant texts there was evidence of a range of dimensions and the range of themes was also applicable. In some cases (see Appendix), the participants demonstrate a similarity to Forster's nurses (Forster, 2015).

The seven themes provide a deep, rich and detailed picture of effective information use within this workplace context and allow some comparison between the nurses, the insurers and the students. They provide evidence that the participants experience variations of dimension similar to those of Forster's nurses, and while these variations differ in detail, still group together under similar themes. Self-development, information sharing, best practice and evidence-based practice, information gathering processes, principles and conceptions are all part of the picture in this context. Naturally the details of these differ, and these differences are made more explicit here by the use of the participants' own terminology, an approach which gives voice to the community. The additional benefit of a language analysis approach is that it allows some comparisons to be made between the two communities of interest here. We saw fewer examples of higher level skills amongst the students, they were using information for a specific purpose (coursework), their instructions and sources were very clearly identified, they were focusing on individual work, and their timescale was generally quite extended, with a specific end date (submission of coursework). The insurance workers, on the other hand, displayed a range of skills across the sample (not always in relation to their age or their experience), worked with vague instruction, were often producing elements of work which informed a wider project, and were working to tight deadlines which meant they could not be comprehensive in their approach. These differences resonate with findings of Abram (2013), O'Farrill (2010) and Goldstein (2014) and strongly support Lloyd's assertions around the contextual nature of IL (2006).

From the examples in Table 2 it can be seen that some progression is required to move through the categories of description, from passive minimalist towards leader, philosopher and strategist. It is suggested that this framework could be used to identify and to develop this progression as an element of workplace learning and staff development. The student personae also provide insights into the semantic gap between their conceptions and those within this workplace context. The personae further demonstrate the differing terminologies used within the workplace and education and have potential to be used to support efforts of transition from HE to insurance work.

The limitations of this work centre on the small sample of students. Although the lack of terms used more than once which are unique to the education texts strongly suggests the students are a looser-knit community than the workplace participants, this is not to say the students do not have their own community (or, more likely, communities) of practice, but the fact they were a very small sample and were drawn from a wide range of courses and experiences may explain this apparent disengagement. A larger sample of students from a more closely related subject area would probably have impacted on this finding, which could be a subject of further work. 


\section{Conclusion and future work}

This paper has explored insurance workers' conceptions of effective information use in a particular firm in some detail and made some comparisons with student and nurses. While we do not make any claims as to the wider generalisability of our findings, the application of Forster's framework allows the identification of some key areas for exploration. In particular:

- the nature of workplace IL in the insurance context as identified and articulated by these participants seems to be contextual and spread over a range of themes (self-development, relationships, best practice, evidence-based practice, application of skills, principles and concepts, conceptions) which partially link to those found in nursing;

- these themes support the view that IL is wider than a task and skills-based approach and should be considered as a more holistic concept;

- the semantic gap between the insurance and education context has allowed us to identify some links between these two communities of practice within the context of the framework, allowing us to tentatively propose that use of the language of the insurance firm would help those aspiring to work in that sector communicate more effectively with potential employers.

Deeper insight into language use has the potential to support human resources staff and careers consultants in identifying and evaluating the levels of IL of their clients and colleagues and contribute to job-hunting and self-development.

Further work is planned to develop an online 'personality test' to support the use of these findings and we also plan to explore the use of language in other professions and workplaces to explore in more detail how language use influences people's conceptions of the information experience. While clearly the contextual nature of IL means that, in the words of Abram, 'it's different' (2013), understanding more about where the similarities as well as the differences lie may help to provide further insights into how transition from education to employment could be supported more effectively.

\section{Acknowledgements}

The authors would like to thank the CILIP Information Literacy Group for funding this research. We would also like to thank the following for their input during the research: Kieron Jones (UCL Library), Steve Rowett (UCL Digital Education), Eleanor Wale (UCL MA LIS student), and the anonymous reviewers who made such helpful contributions. Most of all we would like to thank our anonymous participants, without whom this research would not have been possible, for their contributions.

\section{References}

Abram, S. (2013). Workplace information literacy: It's different. In M. Hepworth, \& G. Walton, (Eds.), Developing people's information capabilities: Fostering information literacy in educational, workplace and community contexts (pp. 205-222). Emerald.

ACRL (2000). Information literacy competency standards for higher education. ALAIR. https://alair.ala.org/handle/11213/7668

Ahmad, F., Widen, G., \& Huvila, I. (2020). The impact of workplace information literacy on organizational innovation: An empirical study. International Journal of Information Management 51. https://doi.org/10.1016/j.ijinfomgt.2019.102041 
ALA (2015). Framework for Information Literacy for Higher Education. American Library Association. http://www.ala.org/acrl/standards/ilframework

Andrews, T. (2012). What is social constructionism? Grounded Theory Review: An International Journal, 11(1). http://groundedtheoryreview.com/2012/06/01/what-is-social-constructionism/

Axelsson, M. L., Brage, C., Gustafsson Åman, K., \& Öström, M. (2017). Mind the gap! Academic information literacy vs workforce information literacy. In 10th Annual International Conference of Education, Research and Innovation (ICERI) (pp. 1508-1518). lated-Int Assoc Technology Education \& Development.

Bates, M. J. (2010). Information behavior. In M. J. Bates \& M. N. Maack (Eds.) Encyclopedia of library and information sciences, 3 (pp. 2381-2391). CRC Press.

Binsfeld, A. (2019). New barristers' information literacy challenges as they transition from education to the workplace. Legal Information Management, 19(1), 36-45.

https://doi.org/10.1017/S1472669619000057

Burr, V. (2003). Social Constructionism. Routledge.

Byström, K., Ruthven, I., \& Heinström, J. (2017). Work and information: Which workplace models still work in modern digital workplaces?. Information Research, 22(1), CoLIS paper 1651. http://InformationR.net/ir/22-1/colis/colis1651.html

Chyung, S. Y., Stepich, D., \& Cox, D. (2006). Building a competency-based curriculum architecture to educate 21 st-century business practitioners. Journal of Education for Business, 81(6), 307-314. https://doi.org/10.3200/JOEB.81.6.307-314

CII (2017). Insurance competency framework. Chartered Insurance Institute. http://www.cii.co.uk/qualifications/qualification-information/insurance-competency-framework/

Conley, T. M. \& Gil, E. L. (2011). Information literacy for undergraduate business students: Examining value, relevancy, and implications for the new century. Journal of Business \& Finance Librarianship, 16(3). 213-228. https://doi.org/10.1080/08963568.2011.581562

Costa, C. (2009). Use of online information resources by RMIT university economics, finance, and marketing students participating in a cooperative education program. Australian Academic \& Research Libraries, 40(1). 36-49. https://doi.org/10.1080/00048623.2009.10721377

Crawford, J. \& Irving, C. (2009). Information literacy in the workplace: A qualitative exploratory study. Journal of Librarianship \& Information Science, 41(1). 29-38.

https://doi.org/10.1177\%2F0961000608099897

Drucker, P. (1994). Infoliteracy. Forbes ASAP Supplement, pp. 104-109.

Forster, M. (2013a). Information literacy as a facilitator of ethical practice in the professions. Journal of Information Literacy, 7(1). 18-29. https://doi.org/10.11645/7.1.1783

Forster, M. (2013b). A phenomenographic investigation into information literacy in nursing practice - Preliminary findings and methodological issue. Nurse Education Today, 33(10). 1237-1241. https://doi.org/10.1016/j.nedt.2012.05.027

Forster, M. (2015). Six ways of experiencing information literacy in nursing: The findings of a phenomenographic study. Nurse Education Today, 35(1). 195-200.

https://doi.org/10.1016/i.nedt.2014.06.005 
Forster, M. (2016). Phenomenography: A methodology for information literacy research. Journal of Librarianship and Information Science, 48(4). 353-362.

https://doi.org/10.1177\%2F0961000614566481

Forster, M. (Ed.). (2017). Information literacy in the workplace. Facet

Forster, M. (2019). 'Ethnographic' thematic phenomenography. Journal of Documentation 75(2). 349-365. https://doi.org/10.1108/JD-05-2018-0079

Fourie, I., \& Julien, H. (2014). IRS, information services and LIS research - a reminder about affect and the affective paradigm ... and a question. Library Hi Tech 32(1). 190-201.

https://doi.org/10.1108/LHT-10-2013-0144

Garner, S. D. (Ed.). (2005). High-level colloquium on information literacy and lifelong learning. IFLA. https://www.ifla.org/files/assets/information-literacy/publications/high-level-colloquium2005.pdf

Gergen, K. J. (2015). An invitation to social construction. Sage.

Gilinsky, A., \& Robison, R. (2008). A proposed design for the business capstone course with emphasis on improving students' information competency. Journal of Management Education, 32(4). 400-419. https://doi.org/10.1177\%2F1052562907307633

Goldstein, S. (2014). Transferring information know-how: Information literacy at the interface between higher education and employment. Informall. https://www.informall.org.uk/wpcontent/uploads/2015/11/Report-on-transferability-of-IL-beyond-academia-FINAL.pdf

Goldstein, S., \& Whitworth, A. (2015). Determining the value of information literacy for employers. In S. Kurbanoglu, J. Boustany, S. Špiranec, E. Grassian, D. Mizrachi, \& L. Roy (Eds.), Information literacy: moving toward sustainability. Third European conference, ECIL 2015 (pp. 70-79). Springer.

Hawes, D. K. (1994). Information literacy and the business schools. Journal of Education for Business, 70(1). 54-61. https://doi.org/10.1080/08832323.1994.10117725

Head, A. J. (2017). Posing the million dollar question: What happens after graduation? Journal of Information Literacy, 11(1). 80-90. https://doi.org/10.11645/11.1.2186

Hein, A. M. (2010). Identification and bridging of semantic gaps in the context of multi-domain engineering. In D. E. Goldberg \& D. P. Michelfelder (Eds.), Abstracts of the 2010 forum on philosophy, engineering \& technology, Colorado School of Mines May 9-10, 2010, (pp. 57-59). Colorado School of Mines.

HESA. (2015). Destinations of leavers from higher education 2013-14. HESA. http://www.hesa.ac.uk/data-and-analysis/publications/destinations-2013-14

Hiemstra, D. (2000). A probabilistic justification for using tf $\times$ idf term weighting in information retrieval. International Journal on Digital Libraries, 3(2). 131-139.

https://doi.org/10.1007/s007999900025

Holland, A. G. (2006). Associating social constructionism and extended cognition in information studies. Journal of Documentation, 62(1). 91-100. https://doi.org/10.1108/00220410610642066

Hwang, Y. (2011). Measuring information behaviour performance inside a company: a case study. Information Research, 16(2). Paper 480. http://InformationR.net/ir/16-2/paper480.html 
Inskip, C. (2014). Information literacy is for life, not just for a good degree: A literature review. UCL Discovery

http://discovery.ucl.ac.uk/1448073/1/IL\%20in\%20the\%20workplace\%20literature\%20review\%2 0Dr\%20C\%20Inskip\%20June\%202014.\%20doc.pdf

Jinadu, I., \& Kaur, K. (2014). Information literacy at the workplace: A suggested model for a developing country. Libri: International Journal of Libraries \& Information Services, 64(1). 61-74. https://doi.org/10.1515/libri-2014-0006

Johnson, I. M. (2013). The impact on education for librarianship and information studies of the Bologna process and related European Commission programmes - and some outstanding issues in Europe and beyond. Education for Information, 30(1-2). 63-92.

https://doi.org/10.3233/efi-130933

Klusek, L., \& Bornstein, J. (2006). Information literacy skills for business careers: Matching skills to the workplace. Journal of Business \& Finance Librarianship, 11(4). 3-21.

https://doi.org/10.1300/J109v11n04 02

Lave, J. and Wenger, E. (1991). Situated learning: Legitimate peripheral participation.

Cambridge UP.

Li, C.K., \& Hung, C.H. (2010). An examination of the mediating role of person-job fit in relations between information literacy and work outcomes. Journal of Workplace Learning, 22(5). 306-

318. https://doi.org/10.1108/13665621011053217

Limberg, L., Sundin, O., \& Talja, S. (2012). Three theoretical perspectives on information literacy. Human IT: Journal for Information Technology Studies as a Human Science, 11(2). 93130.

Lloyd, A. (2006). Information literacy landscapes: An emerging picture. Journal of Documentation, 62(5). 570-583. https://doi.org/10.1108/00220410610688723

Lloyd, A. (2010). Framing information literacy as information practice: Site ontology and practice theory. Journal of Documentation 66(2). 245-58. https://doi.org/10.1108/00220411011023643

Lloyd, A. (2011). Trapped between a rock and a hard place: What counts as information literacy in the workplace and how is it conceptualized? Library Trends, 60(2). 277-296.

https://doi.org/10.1353/lib.2011.0046

Lloyd, A. (2012). Information literacy as a socially enacted practice: Sensitising themes for an emerging perspective of people-in-practice. Journal of Documentation, 68(6), 772-783.

https://doi.org/10.1108/00220411211277037

Lloyd, A., \& Somerville, M. (2006). Working information. Journal of Workplace Learning, 18(3). 186-198.

Lockerbie, H., \& Williams, D. (2019). Seven pillars and five minds: small business workplace information literacy. Journal of Documentation, 75(5). 977-994. http://dx.doi.org/10.1108/JD-09$\underline{2018-0151}$

Lundh, A. H., Limberg, L. and Lloyd, A. (2013). Swapping settings: Researching information literacy in workplace and in educational contexts. Information Research - an International Electronic Journal, 18(3). Paper C05. 
Malafi, E., Liu, G., \& Goldstein, S. (2017). Business and workplace information literacy: Three perspectives. Reference \& User Services Quarterly, 57(2). 79-85.

https://doi.org/10.5860/rusq.57.2.6521

Marchand, D., Kettinger, W. J., \& D. Rollins, J. D. (2000). Information orientation: People, technology and the bottom line. Sloan Management Review 41(4). 69-80.

Marton, F. (1986). Phenomenography - A research approach to investigating different understandings of reality. Journal of Thought, 21(3). 28-49.

Mawson, M., \& Haworth, A. C. (2018). Supporting the employability agenda in university libraries. Information and Learning Science, 119(1/2). 101-108. http://dx.doi.org/10.1108/ILS-04$\underline{2017-0027}$

Molopyane, J., \& Fourie, I. (2015). A framework for workplace information literacy in academic contexts: Central University of Technology, Free State (South Africa) as case study. Library Hi Tech, 33(4). 562-583. https://doi.org/10.1108/LHT-02-2015-0013

Natt, A. (2013). What Is business information literacy and can the corporate librarian contribute anything to the discourse?. Journal of Business \& Finance Librarianship, 18(2). 146-174. https://doi.org/10.1080/08963568.2013.769290

Nonaka, I. \& Takeuchi, H. (1995). The knowledge-creating company: How Japanese companies create the dynamics of innovation. Oxford UP.

O'Farrill, R. T. (2010). Information literacy and knowledge management at work: Conceptions of effective information use at NHS24. Journal of Documentation, 66(5). 706-733.

https://doi.org/10.1108/00220411011066808

O'Sullivan, C. (2002). Is information literacy relevant in the real world?. Reference Services Review, 30(1). 7-14. https://doi.org/10.1108/00907320210416492

Paisley, W. J. (1968). Information needs and uses. Annual review of information science and technology, 3(1). 1-30.

Pavlina, K., Spiranec, S., \& Pavlina, A. P. (2014). Information competences - students' perspective. In 2014 37th International Convention on Information and Communication Technology, Electronics and Microelectronics (Mipro) (pp. 778-781). IEEE.

Phillips, M., Fosmire, M., Turner, L., Petersheim, K., \& Lu, J. (2019). Comparing the information needs and experiences of undergraduate students and practicing engineers. Journal of Academic Librarianship 45(1). 39-49. https://doi.org/10.1016/j.acalib.2018.12.004

Popescu, I. (2007). Text ranking by the weight of highly frequent words. In P. Grzybek \& R. Köhler (Eds.), Exact Methods in the Study of Language and Text (pp. 555-566). De Gruyter.

Porter, M. and Millar, V. (1985). How information gives you competitive advantage. Harvard Business Review, 63(4). 149-160.

Prince, M., Burns, D., Lu, X., \& Winsor, R. (2015). Knowledge and skills transfer between mba and workplace. Journal of Workplace Learning 27(3). 207-25. https://doi.org/10.1108/JWL-06$\underline{2014-0047}$

QAA. (2014). Subject benchmark statements. The Quality Assurance Agency for Higher Education (QAA). https://www.qaa.ac.uk/quality-code/subject-benchmark-statements 
Quinn, T., \& Leligdon, L. (2014). Executive MBA students' information skills and knowledge: Discovering the difference between work and academics. Journal of Business \& Finance Librarianship, 19(3). 234-255. https://doi.org/10.1080/08963568.2014.916540

Rees, C., Forbes, P., \& Kubler, B. (2006). Student Employability Profiles. AdvanceHE. https://www.heacademy.ac.uk/system/files/student employability profiles apr07.pdf

Savolainen, R. (2007). Information behavior and information practice: Reviewing the umbrella concepts of information seeking studies. The Library Quarterly, 77(2). 109-132.

https://doi.org/10.1086/517840

Schmitt, N. (2010). An introduction to applied linguistics. Hodder Education.

SCONUL. (2011). The SCONUL seven pillars of information literacy: Core model. SCONUL. https://www.sconul.ac.uk/page/seven-pillars-of-information-literacy

Secker, J. (2018). The revised CILIP definition of information literacy. Journal of Information Literacy, 12(1). 156-158. https://doi.org/10.11645/12.1.2454

Sharun, S. 2019. Exploring value as a dimension of professional information literacy. Journal of Information Literacy, 13(2). 26-40. https://doi.org/10.11645/13.2.2627

Talja, S., Tuominen, K., \& Savolainen, R. (2005). 'Isms' in information science: Constructivism, collectivism and constructionism. Journal of Documentation, 61(1). 79-101.

https://doi.org/10.1108/00220410510578023

Teubert, W., \& Čermáková, A. (2007). Corpus linguistics: A short introduction. Continuum.

Tuominen, K., Savolainen, R., \& Talja, S. (2005). Information literacy as a sociotechnical practice. The Library Quarterly, 75(3), 329-345. http://dx.doi.org/10.1086/497311

Wadson, K., \& Phillips, L. A. (2018). Information literacy skills and training of licensed practical nurses in Alberta, Canada: Results of a survey. Health Information \& Libraries Journal, 35(2). 141-159. https://doi.org/10.1111/hir.12217

Wema, E. (2013). Workplace reflections of information literacy training: The case of the agriculture and health sectors in tanzania. In M. Hepworth \& G. Walton (Eds.), Developing people's information capabilities: Fostering information literacy in educational, workplace and community contexts (pp. 179-201). Emerald.

Widén-Wulff, G. (2003). Information as a resource in the insurance business: The impact of structures and processes on organization information behaviour. The New Review of Information Behaviour Research, 4(1). 79-94. https://doi.org/10.1080/14716.310310001631453

Wiley, M. (2014). A review of the literature on current practice in the development of employability skills. SCONUL.

https://www.sconul.ac.uk/sites/default/files/documents/Employability\%20Literature\%20Review\% 20June\%202014 0.pdf

Williams, D., Cooper, K., \& Wavell, C. (2014). Information literacy in the workplace: An annotated bibliography. Informall. https://www.informall.org.uk/wp-

content/uploads/2015/11/Workplace-IL-annotated-bibliography.pdf 
Yates, C., Partridge, H. L., \& Bruce, C. S. (2012). Exploring information experiences through phenomenography. Library and Information Research, 36(112). 96-119.

https://doi.org/10.29173/lirg496

Zhang, X., Majid, S., \& Foo, S. (2010). Environmental scanning: An application of information literacy skills at the workplace. Journal of Information Science, 36(6). 719-732.

https://doi.org/10.1177\%2F0165551510385644

Zurkowski, P. G. (1974). The information service environment relationships and priorities. related paper no. 5 [microform]. ERIC Clearinghouse.

\section{Appendix}

This table includes texts updating Forster's categories of description to reflect the practices of the participants in this research. The headings are Forster's. Empty cells were uncoded.

\begin{tabular}{|c|c|c|c|}
\hline & \multicolumn{3}{|c|}{ Passive minimalist } \\
\hline Code & Insurance worker & Student & $\begin{array}{l}\text { Nurse } \\
\text { (all cells in this column: } \\
\text { Forster, 2015, pp. 197- } \\
199 \text { ) }\end{array}$ \\
\hline SDV-A & $\begin{array}{l}\text { I have been studying } \\
\text { and researching the } \\
\text { insurance information } \\
\text { field and language. I } \\
\text { develop key technical } \\
\text { skills I need (eg MS } \\
\text { Office). }\end{array}$ & $\begin{array}{l}\text { I make the most of the } \\
\text { resources provided by } \\
\text { my course tutors e.g. } \\
\text { reading lists ensuring I'm } \\
\text { familiar with the } \\
\text { curriculum }\end{array}$ & $\begin{array}{l}\text { "A. Seeking out } \\
\text { knowledge of clinical } \\
\text { contexts and conditions } \\
\text { - Investigate newly } \\
\text { encountered clinical } \\
\text { conditions/situations" }\end{array}$ \\
\hline REL-A & $\begin{array}{l}\text { I am good at identifying } \\
\text { friendly experts who } \\
\text { are able and willing to } \\
\text { give me relevant } \\
\text { information and advice. }\end{array}$ & $\begin{array}{l}\text { I am good at identifying } \\
\text { helpful experts who are } \\
\text { able and willing to give } \\
\text { me relevant information, } \\
\text { support and advice. I } \\
\text { seek guidance from } \\
\text { people who know more } \\
\text { than I do, like my } \\
\text { lecturers, coursemates, } \\
\text { friends, and library staff. I } \\
\text { ask questions and } \\
\text { request feedback on my } \\
\text { work from lecturers, in } \\
\text { order to perform better. }\end{array}$ & $\begin{array}{l}\text { "A. Interacting passively } \\
\text { with others - others as a } \\
\text { source of information } \\
\text { - Receiving information } \\
\text { from patients, colleagues } \\
\text { and other professionals" }\end{array}$ \\
\hline BES-A & $\begin{array}{l}\text { I have good baseline } \\
\text { skills which follow } \\
\text { policy and protocols. I } \\
\text { am willing to build on } \\
\text { these skills and have } \\
\text { an inquisitive and } \\
\text { positive attitude to } \\
\text { learning. }\end{array}$ & & $\begin{array}{l}\text { "A. Practising with } \\
\text { sufficient background } \\
\text { information } \\
\text { - Obtaining sufficient } \\
\text { background psycho-socio- } \\
\text { cultural background } \\
\text { knowledge on a patient }\end{array}$ \\
\hline
\end{tabular}




\begin{tabular}{|c|c|c|c|}
\hline & & & $\begin{array}{l}\text { - Determining the most } \\
\text { cost-effective / efficient } \\
\text { treatment option" }\end{array}$ \\
\hline EBP-A & $\begin{array}{l}\text { I seek out ways to } \\
\text { understand the } \\
\text { process of insurance. I } \\
\text { follow guidelines, } \\
\text { protocols and policy } \\
\text { documents. }\end{array}$ & & $\begin{array}{l}\text { "A. Obtaining instruction } \\
\text { in / seeking to understand } \\
\text { the process of care } \\
\text { - Following guidelines, } \\
\text { protocols and policy } \\
\text { documents" }\end{array}$ \\
\hline SKL-A & $\begin{array}{l}\text { I confidently use } \\
\text { software to help } \\
\text { manage and interpret } \\
\text { numerical data } \\
\text { efficiently. }\end{array}$ & & $\begin{array}{l}\text { "A. Having the basic } \\
\text { background competencies } \\
\text { - Negotiating the } \\
\text { technology" }\end{array}$ \\
\hline PRI-A & $\begin{array}{l}\text { I have background } \\
\text { technical knowledge of } \\
\text { information sources } \\
\text { and types needed to } \\
\text { research and use data } \\
\text { and information - such } \\
\text { as professional } \\
\text { subscription sources } \\
\text { for the sector and } \\
\text { internal databases. }\end{array}$ & $\begin{array}{l}\text { I am aware of information } \\
\text { sources and types } \\
\text { needed to research and } \\
\text { use data and information. } \\
\text { I know which ones are } \\
\text { considered credible - } \\
\text { such as the FT, The } \\
\text { Economist, JSTOR and } \\
\text { special library resources, } \\
\text { as well as articles } \\
\text { recommended by } \\
\text { lecturers. }\end{array}$ & $\begin{array}{l}\text { "A. Having the } \\
\text { background technical } \\
\text { knowledge of information } \\
\text { sources and } \\
\text { types, needed to find and } \\
\text { use evidence } \\
\text { - Having knowledge of } \\
\text { information types } \\
\text { - Having knowledge of } \\
\text { correct / credible } \\
\text { sources/databases" }\end{array}$ \\
\hline CON-A & $\begin{array}{l}\text { I usually think about } \\
\text { basic financial and } \\
\text { insurance data and } \\
\text { terminology. }\end{array}$ & & $\begin{array}{l}\text { "A. Basic facts } \\
\text { - Basic clinical and } \\
\text { scientific knowledge of a } \\
\text { condition" }\end{array}$ \\
\hline & \multicolumn{3}{|c|}{ Knowledgeable goal achiever } \\
\hline SDV-B & $\begin{array}{l}\text { I have developed my } \\
\text { understanding of } \\
\text { insurance principles } \\
\text { from learning on-the- } \\
\text { job, a professional } \\
\text { qualification, and ad } \\
\text { hoc support. }\end{array}$ & $\begin{array}{l}\text { As well as using } \\
\text { resources provided by } \\
\text { tutors, l've improved my } \\
\text { skills, and learned new } \\
\text { ones, by taking extra } \\
\text { courses e.g. those } \\
\text { provided by the library or } \\
\text { online learning platforms. }\end{array}$ & $\begin{array}{l}\text { "B. Being a } \\
\text { knowledgeable nurse } \\
\text { - Establishing knowledge } \\
\text { of, and understanding of, } \\
\text { current practice and } \\
\text { associate issues" }\end{array}$ \\
\hline REL-B & $\begin{array}{l}\text { I participate in sharing } \\
\text { knowledge internally } \\
\text { and externally to } \\
\text { provide clear } \\
\text { information which } \\
\text { benefits the business. }\end{array}$ & $\begin{array}{l}\text { I have discussions and } \\
\text { debates with my peers, } \\
\text { and sometimes with my } \\
\text { lecturers. I share my } \\
\text { ideas and knowledge } \\
\text { around assignments, and } \\
\text { benefit from theirs. }\end{array}$ & $\begin{array}{l}\text { "B. Interacting actively-a } \\
\text { give and take of } \\
\text { information } \\
\text { - Sharing information" }\end{array}$ \\
\hline
\end{tabular}




\begin{tabular}{|c|c|c|c|}
\hline BES-B & $\begin{array}{l}\text { I can identify which } \\
\text { information is relevant } \\
\text { to use as evidence. I } \\
\text { can communicate it in } \\
\text { a straightforward way } \\
\text { which is } \\
\text { understandable and } \\
\text { balanced, and reflects } \\
\text { a plethora of views. }\end{array}$ & & $\begin{array}{l}\text { "B. Helping the team } \\
\text { practice with sufficient } \\
\text { information to function } \\
\text { - Contributing evidence } \\
\text { and other information to } \\
\text { the Multidisciplinary team" }\end{array}$ \\
\hline EBP-B & $\begin{array}{l}\text { I use up-to-date and } \\
\text { relevant evidence to } \\
\text { inform business } \\
\text { decisions. }\end{array}$ & & $\begin{array}{l}\text { "B. Focusing on relevant } \\
\text { evidence } \\
\text { - Matching evidence to a } \\
\text { very specific clinical } \\
\text { context or specific patient } \\
\text { - Using evidence to } \\
\text { prompt additional, more } \\
\text { detailed questions } \\
\text { - Keeping up to date with } \\
\text { the current evidence } \\
\text { relevant to your job" }\end{array}$ \\
\hline SKL-B & $\begin{array}{l}\text { I'm able to find relevant } \\
\text { data and information } \\
\text { from a range of } \\
\text { sources. }\end{array}$ & $\begin{array}{l}\text { I know where the library } \\
\text { is, and how to use it - } \\
\text { both the online and } \\
\text { offline resources. I don't } \\
\text { usually have much of a } \\
\text { search plan, but using } \\
\text { these resources, I pick up } \\
\text { what I need as I go } \\
\text { along. }\end{array}$ & $\begin{array}{l}\text { "B. Achieving } \\
\text { 'Knowledgeable' } \\
\text { functionality } \\
\text { • Knowing how to use a } \\
\text { library/ Library resource } \\
\text { website" }\end{array}$ \\
\hline PRI-B & $\begin{array}{l}\text { I have the experience } \\
\text { to understand the } \\
\text { complexities, terms } \\
\text { and structures of } \\
\text { insurance information } \\
\text { and research. }\end{array}$ & & $\begin{array}{l}\text { "B. Being knowledgeable } \\
\text { in medical information and } \\
\text { research } \\
\text { - Having an } \\
\text { understanding of the } \\
\text { complexities, meanings } \\
\text { and structures } \\
\text { of medical information } \\
\text { and research evidence" }\end{array}$ \\
\hline CON-B & $\begin{array}{l}\text { I understand useful } \\
\text { qualitative and } \\
\text { quantitative data } \\
\text { including economic } \\
\text { and technical data, } \\
\text { metadata, trends and } \\
\text { data from clients and } \\
\text { internal sources. }\end{array}$ & $\begin{array}{l}\text { I understand that there is } \\
\text { a lot of data out there, } \\
\text { but only some of it will be } \\
\text { useful data and relevant } \\
\text { data. What my lecturers } \\
\text { recommend is usually a } \\
\text { good start when } \\
\text { considering useful and } \\
\text { important data. }\end{array}$ & $\begin{array}{l}\text { "B. Useful Data } \\
\text { - Statistical data } \\
\text { - Data generated from } \\
\text { patients (or via } \\
\text { colleagues) and the } \\
\text { clinical Situation" }\end{array}$ \\
\hline & \multicolumn{3}{|c|}{ Focussed, competent and evolving professional } \\
\hline
\end{tabular}




\begin{tabular}{|c|c|c|c|}
\hline SDV-C & $\begin{array}{l}\text { I have gone beyond } \\
\text { the training, and have } \\
\text { practised complex } \\
\text { processes. I have } \\
\text { shared my experiences } \\
\text { with others. }\end{array}$ & & $\begin{array}{l}\text { "C. Achieving professional } \\
\text { competence } \\
\text { - Showing competence in } \\
\text { day to day work" }\end{array}$ \\
\hline REL-C & $\begin{array}{l}\text { I interact with other } \\
\text { team members to } \\
\text { circulate a broad and } \\
\text { deep stream of } \\
\text { business information } \\
\text { through the company. }\end{array}$ & $\begin{array}{l}\text { I am part of informal or } \\
\text { formal peer networks with } \\
\text { other students. We } \\
\text { interact, collbaorate and } \\
\text { exchange ideas, } \\
\text { supporting eachother to } \\
\text { keep our individual or } \\
\text { joint work moving in the } \\
\text { right direction. My peers } \\
\text { value my input and ask } \\
\text { for my help. }\end{array}$ & $\begin{array}{l}\text { "C. Developing functional } \\
\text { relationships } \\
\text { - Functioning as part of } \\
\text { the multi-disciplinary } \\
\text { team" }\end{array}$ \\
\hline BES-C & $\begin{array}{l}\text { I regularly check my } \\
\text { work and the work of } \\
\text { others. I can engage in } \\
\text { the peer review } \\
\text { process within tight } \\
\text { deadlines to ensure } \\
\text { accuracy and minimise } \\
\text { business risk. }\end{array}$ & & $\begin{array}{l}\text { "C. Using evidence as a } \\
\text { tool for 'improvement' } \\
\text { - Attempting to improve } \\
\text { individual outcomes } \\
\text { - Attempting to 'improve } \\
\text { my practice' } \\
\text { - Suggesting a change in } \\
\text { practice" }\end{array}$ \\
\hline EBP-C & $\begin{array}{l}\text { I search for new } \\
\text { information, and } \\
\text { integrate this with my } \\
\text { existing knowledge. I } \\
\text { draw commercial } \\
\text { conclusions based on } \\
\text { my own judgment and } \\
\text { the evidence. }\end{array}$ & & $\begin{array}{l}\text { "C. Seeking evidence to } \\
\text { integrate into existing } \\
\text { knowledge and } \\
\text { experience } \\
\text { - Contextualizing of } \\
\text { evidence by judgement } \\
\text { and knowledge / Allowing } \\
\text { judgement and knowledge } \\
\text { to evolve in light of } \\
\text { awareness of evidence" }\end{array}$ \\
\hline SKL-C & $\begin{array}{l}\text { I enjoy the research } \\
\text { process, and I have an } \\
\text { eye for detail, which } \\
\text { helps me to identify } \\
\text { quality information. }\end{array}$ & $\begin{array}{l}\text { I use a range of libraries } \\
\text { and search engines to } \\
\text { gather information. I first } \\
\text { gather an overview of the } \\
\text { subject area and main } \\
\text { concepts using } \\
\text { appropriate high-level } \\
\text { sources, then focus down } \\
\text { on the specific details I } \\
\text { need e.g in journal } \\
\text { articles. I am able to use } \\
\text { Google and other search } \\
\text { engines and other } \\
\text { libraries. }\end{array}$ & $\begin{array}{l}\text { "C. Achieving 'skilled' } \\
\text { functionality } \\
\text { - Practising time efficient } \\
\text { information gathering } \\
\text { - Structuring evidence } \\
\text { searches effectively" }\end{array}$ \\
\hline
\end{tabular}




\begin{tabular}{|c|c|c|c|}
\hline PRI-C & $\begin{array}{l}\text { I'm aware of technical } \\
\text { functions within data } \\
\text { analysis (eg pivot } \\
\text { tables) and understand } \\
\text { how to apply these } \\
\text { effectively to explore } \\
\text { large fields of data. }\end{array}$ & $\begin{array}{l}\text { I'm aware of the } \\
\text { differences between } \\
\text { different information } \\
\text { sources, and their } \\
\text { structures, and therefore } \\
\text { which source to use for } \\
\text { which purpose. }\end{array}$ & $\begin{array}{l}\text { "C. Being knowledgeable } \\
\text { of functions within } \\
\text { information gathering } \\
\text { - Having knowledge of } \\
\text { database/information } \\
\text { source structure and } \\
\text { functions" }\end{array}$ \\
\hline \multirow[t]{2}{*}{ CON-C } & $\begin{array}{l}\text { I appreciate the } \\
\text { importance of agreed } \\
\text { definitions of } \\
\text { terminology. }\end{array}$ & $\begin{array}{l}\text { I often use and think } \\
\text { about all the information } \\
\text { that is widely available to } \\
\text { me, online and though } \\
\text { my university, as a } \\
\text { means of improving my } \\
\text { skills and performance. }\end{array}$ & $\begin{array}{l}\text { "C. Guides to achieve } \\
\text { competence } \\
\text { - Clinical guidelines, } \\
\text { protocols and care } \\
\text { bundles" }\end{array}$ \\
\hline & \multicolumn{3}{|c|}{ Confident and trusted promoter of justifiable change } \\
\hline SDV-D & $\begin{array}{l}\text { My level of } \\
\text { competence has been } \\
\text { recognised formally } \\
\text { through appraisals and } \\
\text { informally through day- } \\
\text { to-day transactions. }\end{array}$ & & $\begin{array}{l}\text { "D. Achieving professional } \\
\text { confidence } \\
\text { - Feeling confident in } \\
\text { one's role } \\
\text { - Progressing } \\
\text { professionally. Becoming } \\
\text { a Lifelong learner" }\end{array}$ \\
\hline REL-D & $\begin{array}{l}\text { I reliably provide } \\
\text { competitive service } \\
\text { and prompt and } \\
\text { accurate information to } \\
\text { clients and colleagues. } \\
\text { I present it in a focused } \\
\text { way so it can be easily } \\
\text { understood. }\end{array}$ & $\begin{array}{l}\text { I participate in } \\
\text { collaborative groups, and } \\
\text { I make an effort to ensure } \\
\text { my peers trust me to } \\
\text { perform my role. I have } \\
\text { my own opinions, and my } \\
\text { peers and lecturers allow } \\
\text { these to influence the } \\
\text { direction of my work and } \\
\text { the work of others. Using } \\
\text { technology to present } \\
\text { collaborative group view. }\end{array}$ & $\begin{array}{l}\text { "D. Developing the trust of } \\
\text { patients, families and } \\
\text { colleagues } \\
\text { - Creating trust in you in } \\
\text { others } \\
\text { - Being seen to be } \\
\text { accountable for actions } \\
\text { - Achieving autonomy and } \\
\text { status within the team" }\end{array}$ \\
\hline BES-D & $\begin{array}{l}\text { I'm involved in } \\
\text { ensuring high quality of } \\
\text { information which is } \\
\text { audited and follows } \\
\text { internal, industry and } \\
\text { regulator guidance. }\end{array}$ & & $\begin{array}{l}\text { "D. Developing strategies } \\
\text { of justifiable change } \\
\text { - Developing up-to-date- } \\
\text { practice } \\
\text { - Developing practice that } \\
\text { is recognised as } \\
\text { objectively proven / } \\
\text { justifiable } \\
\text { - Developing rationales for } \\
\text { change" }\end{array}$ \\
\hline EBP-D & $\begin{array}{l}\text { I understand the } \\
\text { importance of } \\
\text { comprehensive, } \\
\text { accurate and relevant }\end{array}$ & & $\begin{array}{l}\text { "D. Experiencing evidence } \\
\text { as a concept }\end{array}$ \\
\hline
\end{tabular}




\begin{tabular}{|c|c|c|c|}
\hline & $\begin{array}{l}\text { evidence. I have the } \\
\text { ability to evaluate this } \\
\text { to minimise financial } \\
\text { risk. }\end{array}$ & & $\begin{array}{l}\text { - Allowing ascientific basis } \\
\text { for practice } \\
\text { - Allowing an objective, } \\
\text { evidentiary underpinning } \\
\text { for practice" }\end{array}$ \\
\hline SKL-D & $\begin{array}{l}\text { I search varied sources } \\
\text { to identify } \\
\text { comprehensive } \\
\text { information and data } \\
\text { which presents a } \\
\text { balanced picture. }\end{array}$ & $\begin{array}{l}\text { I have a clear plan for my } \\
\text { search that utilises a } \\
\text { range of high-level and } \\
\text { very specific sources e.g. } \\
\text { textbooks to journal } \\
\text { articles. I am confident } \\
\text { that I know when I have } \\
\text { found all relevant } \\
\text { information, and my } \\
\text { search is finished. I use } \\
\text { Google Scholar and a } \\
\text { variety of textbooks and } \\
\text { (sometimes) journals. }\end{array}$ & $\begin{array}{l}\text { "D. Operating coherently } \\
\text { in processes of evidence } \\
\text { and other information } \\
\text { gathering } \\
\text { - Finding all or sufficient } \\
\text { evidence" }\end{array}$ \\
\hline PRI-D & $\begin{array}{l}\text { I have knowledge of } \\
\text { how to use keyword } \\
\text { searching effectively }\end{array}$ & & $\begin{array}{l}\text { "D. Being knowledgeable } \\
\text { of search syntax } \\
\text { - Having knowledge of } \\
\text { MeSH, subject headings, } \\
\text { textwords and how they } \\
\text { can be used" }\end{array}$ \\
\hline CON-D & $\begin{array}{l}\text { I appreciate that data } \\
\text { and information have a } \\
\text { context, which can help } \\
\text { investigate deeper. }\end{array}$ & $\begin{array}{l}\text { I appreciate that data and } \\
\text { information have a } \\
\text { context, and } \\
\text { understanding that } \\
\text { context through wider } \\
\text { reading helps explain the } \\
\text { meaning behind data. }\end{array}$ & $\begin{array}{l}\text { "D. As a means of } \\
\text { achieving a wider and } \\
\text { deeper understanding of a } \\
\text { clinical } \\
\text { phenomenon } \\
\text { - A means of } \\
\text { understanding a newly } \\
\text { encountered clinical } \\
\text { problem or } \\
\text { phenomenon } \\
\text { - A means to enable } \\
\text { deeper investigation" }\end{array}$ \\
\hline & \multicolumn{3}{|c|}{ Teacher and promoter of an evidence-based culture } \\
\hline SDV-E & $\begin{array}{l}\text { I have a deeper } \\
\text { understanding of } \\
\text { insurance information } \\
\text { through higher level } \\
\text { skills and experience. }\end{array}$ & & $\begin{array}{l}\text { "E. Achieving functional } \\
\text { autonomy } \\
\text { - Becoming an adaptable, } \\
\text { flexible and responsive } \\
\text { professional } \\
\text { - Becoming able to } \\
\text { function non-dependently } \\
\text { within the team" }\end{array}$ \\
\hline REL-E & $\begin{array}{l}\text { I often act as a mentor } \\
\text { or teacher for junior } \\
\text { colleagues and other } \\
\text { members of the team. }\end{array}$ & & $\begin{array}{l}\text { "E. Developing a teaching } \\
\text { role }\end{array}$ \\
\hline
\end{tabular}




\begin{tabular}{|c|c|c|c|}
\hline & & & $\begin{array}{l}\text { - Functioning as a teacher } \\
\text { for junior colleagues and } \\
\text { other members of } \\
\text { the team" }\end{array}$ \\
\hline BES-E & $\begin{array}{l}\text { I am aware of the role } \\
\text { data and information } \\
\text { play in predicting } \\
\text { financial risk and } \\
\text { making business } \\
\text { decisions. }\end{array}$ & & $\begin{array}{l}\text { "E. Developing an } \\
\text { information rich culture } \\
\text { - Developing a culture of } \\
\text { change within the ward } \\
\text { - Developing a culture of } \\
\text { accountability to patients } \\
\text { - Developing an evidence- } \\
\text { based ward culture" }\end{array}$ \\
\hline EBP-E & $\begin{array}{l}\text { I use internal data and } \\
\text { information as an audit } \\
\text { tool to develop insights } \\
\text { and comparisons } \\
\text { leading to } \\
\text { developments in policy } \\
\text { and protocols. }\end{array}$ & & $\begin{array}{l}\text { "E. Experiencing evidence } \\
\text { as a tool within policy } \\
\text { - Auditing practice } \\
\text { - Developing of protocols } \\
\text { and guidelines" }\end{array}$ \\
\hline SKL-E & $\begin{array}{l}\text { I scan purposefully and } \\
\text { pick relevant data and } \\
\text { information from } \\
\text { authoritative sources. I } \\
\text { can accurately and } \\
\text { concisely analyse and } \\
\text { summarise it for } \\
\text { colleagues. }\end{array}$ & $\begin{array}{l}\text { My clear search strategy } \\
\text { identifies all relevant } \\
\text { information, which I am } \\
\text { able to categorise, } \\
\text { prioritise, and critique, so } \\
\text { I use only the most } \\
\text { appropriate information } \\
\text { and techniques in my } \\
\text { work. }\end{array}$ & $\begin{array}{l}\text { "E. Operating purposefully } \\
\text { in processes of evidence } \\
\text { and other information } \\
\text { gathering } \\
\text { - Critiquing relevant } \\
\text { evidence effectively } \\
\text { - Gathering and applying } \\
\text { key information within the } \\
\text { ward environment } \\
\text { - Gathering evidence } \\
\text { effectively for a team, or } \\
\text { group project:guideline } \\
\text { development or policy } \\
\text { change" }\end{array}$ \\
\hline PRI-E & $\begin{array}{l}\text { I understand how to } \\
\text { structure searches } \\
\text { when I need to gather } \\
\text { information. }\end{array}$ & $\begin{array}{l}\text { I am aware of ways to } \\
\text { structure a search by } \\
\text { breaking down piece of } \\
\text { work into specific } \\
\text { problems. }\end{array}$ & $\begin{array}{l}\text { "E. Being knowledgeable } \\
\text { of search strategy } \\
\text { - Having knowledge of the } \\
\text { structuring of searches" }\end{array}$ \\
\hline CON-E & $\begin{array}{l}\text { I think about the } \\
\text { importance of } \\
\text { information in terms of } \\
\text { the contribution it can } \\
\text { make to problem- } \\
\text { solving and as a } \\
\text { rationale for business } \\
\text { development. }\end{array}$ & $\begin{array}{l}\text { I see data as a means to } \\
\text { back up arguments and } \\
\text { produce useful new } \\
\text { points that can have real } \\
\text { effects. Searching for } \\
\text { extra details and doing } \\
\text { my own analysis can help } \\
\text { make a difference. }\end{array}$ & $\begin{array}{l}\text { "E. As a basis for practice } \\
\text { - Evidence to inform } \\
\text { practice } \\
\text { - A means of developing } \\
\text { relationships" }\end{array}$ \\
\hline & \multicolumn{3}{|c|}{ Leader, philosopher and strategist } \\
\hline
\end{tabular}




\begin{tabular}{|c|c|c|c|}
\hline SDV-F & $\begin{array}{l}\text { I am equipped to } \\
\text { critically reflect on } \\
\text { insurance information } \\
\text { that is passed to me. I } \\
\text { use this to form } \\
\text { arguments and } \\
\text { develop wider business } \\
\text { strategy. }\end{array}$ & & $\begin{array}{l}\text { "F. Having the ability to } \\
\text { think strategically and } \\
\text { philosophically } \\
\text { - Becoming innovative in } \\
\text { practice } \\
\text { - Developing a wider } \\
\text { professional horizon" }\end{array}$ \\
\hline REL-F & $\begin{array}{l}\text { I ensure processes are } \\
\text { in place to allow the } \\
\text { sharing of information } \\
\text { and ideas with me and } \\
\text { others. }\end{array}$ & & $\begin{array}{l}\text { "F. Developing a } \\
\text { leadership role } \\
\text { - Becoming a patient } \\
\text { advocate } \\
\text { - Fulfilling a leadership } \\
\text { role within the team" }\end{array}$ \\
\hline BES-F & $\begin{array}{l}\text { I understand how best } \\
\text { practice impacts the } \\
\text { business. I recognise } \\
\text { the vital role accurate } \\
\text { information and data } \\
\text { play in profitable } \\
\text { operations, company } \\
\text { performance and } \\
\text { competitive advantage. }\end{array}$ & & $\begin{array}{l}\text { "F. Developing an } \\
\text { information supported } \\
\text { ethical focus to care } \\
\text { - Exploring the } \\
\text { parameters of } \\
\text { compassionate care } \\
\text { - Facilitating patient safety } \\
\text { - Achieving optimum and } \\
\text { so ethically defensible } \\
\text { care" }\end{array}$ \\
\hline EBP-F & $\begin{array}{l}\text { I creatively explore } \\
\text { ideas. I draw from } \\
\text { experience and reliable } \\
\text { information to present } \\
\text { a story which } \\
\text { contributes to the } \\
\text { organisation's } \\
\text { reputation. }\end{array}$ & & $\begin{array}{l}\text { "F. Experiencing evidence } \\
\text { as contributing to an } \\
\text { practice ideal } \\
\text { - Allowing experience and } \\
\text { evidence to create an } \\
\text { integrated mutually } \\
\text { informing basis for } \\
\text { practice" }\end{array}$ \\
\hline SKL-F & $\begin{array}{l}\text { I understand the } \\
\text { strategic and decision- } \\
\text { making purpose of the } \\
\text { data and information } \\
\text { being gathered and the } \\
\text { contribution it will make } \\
\text { to the business. }\end{array}$ & $\begin{array}{l}\text { I have a clear } \\
\text { understanding of my } \\
\text { overall goal. My search } \\
\text { strategy, and everything I } \\
\text { do during my search, } \\
\text { works towards that goal. } \\
\text { The information I gather } \\
\text { and use serves a } \\
\text { purpose. I use it to inform } \\
\text { and back up my own } \\
\text { arguments, analysis, and } \\
\text { ideas. }\end{array}$ & $\begin{array}{l}\text { "F. Operating 'organically' } \\
\text { in processes of evidence } \\
\text { and other information } \\
\text { gathering } \\
\text { - Having 'clarity of } \\
\text { purpose and action' when } \\
\text { gathering evidence" }\end{array}$ \\
\hline PRI-F & $\begin{array}{l}\text { I appreciate the } \\
\text { ultimate purpose for } \\
\text { the business in } \\
\text { information gathering. I } \\
\text { fully understand the }\end{array}$ & $\begin{array}{l}\text { I understand that } \\
\text { information gathering has } \\
\text { an objective, and I'm } \\
\text { aware of techniques that } \\
\text { help pull arguments }\end{array}$ & $\begin{array}{l}\text { "F. Having a grasp of } \\
\text { 'purpose' in Information } \\
\text { gathering }\end{array}$ \\
\hline
\end{tabular}




\begin{tabular}{|c|c|c|c|}
\hline & $\begin{array}{l}\text { need before I set out to } \\
\text { do the task. }\end{array}$ & $\begin{array}{l}\text { together with analysis of } \\
\text { data to answer the } \\
\text { question at hand e.g. } \\
\text { PEST analysis. }\end{array}$ & $\begin{array}{l}\text { - Understanding how to } \\
\text { respond to an information } \\
\text { need" }\end{array}$ \\
\hline CON-F & $\begin{array}{l}\text { I see data and } \\
\text { information as a basis } \\
\text { for predicting future } \\
\text { events, reducing } \\
\text { uncertainty, and } \\
\text { informing strategy } \\
\text { development. }\end{array}$ & $\begin{array}{l}\text { I see data and } \\
\text { information as things that } \\
\text { need to be processed } \\
\text { using critical thinking, to } \\
\text { provide the basis for } \\
\text { actual change, strategy } \\
\text { or theory that in future } \\
\text { will be beneficial in the } \\
\text { real world. }\end{array}$ & $\begin{array}{l}\text { "F. As a basis for strategy } \\
\text { guideline protocol or } \\
\text { bundle } \\
\text { - A means to facilitate } \\
\text { change } \\
\text { - A means of developing a } \\
\text { strategy or theory" }\end{array}$ \\
\hline
\end{tabular}

